\title{
NASA aims high with orbital transport system
}

Tony Reichhardt, Washington

If it works, it could revolutionize space transportation. So NASA last week made a small but significant investment in a controversial technique for moving satellites around in orbit using slingshot-like tethers.

The technology works in two stages. First, satellites are boosted into higher orbits using a tether, perhaps $100 \mathrm{~km}$ or longer, that is rotating around an orbiting mass. A grapple mechanism at one end of the tether captures the satellite at the low point of the tether's rotation, then flings it into a higher orbit (see diagram).

The transfer of momentum from the tether to the satellite leaves the tether in a lower orbit. So the second stage of the process uses a power source on the central mass to run an electric current through the tether. Once the current is flowing, the tether experiences a force that results from its movement through Earth's magnetic field. This pushes it back into its original orbit.

NASA doesn't expect to see this kind of tether system demonstrated before 2010, but has awarded $\$ 4$ million to four teams work-

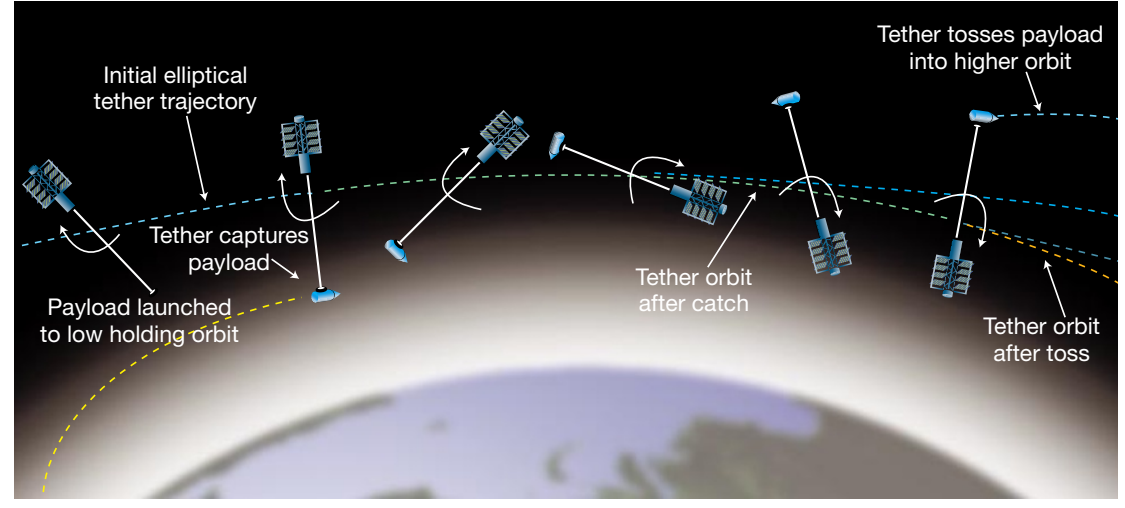

Swinging time: a rotating tether could be used to grab a satellite and toss it into a higher orbit.

ing on it, as part of a programme designed to foster innovative propulsion concepts. The technology, known as MomentumExchange/Electrodynamic-Reboost, will be evaluated over two years using computer simulations and other basic research.

The idea of tether propulsion is an old one but it has yet to prove itself, says Enrico Lorenzini, head of a space-tethers research

\section{Legal row looms for gene-map firm}

\section{Rex Dalton, San Diego}

A leading company in the International HapMap Project, a collaboration aiming to map genetic variation in the human genome, is embroiled in a high-stakes legal battle.

At $\$ 120$ million, HapMap is one of the largest genetics projects since the sequencing of the human genome. Researchers plan to use five separate technologies to identify patterns of genetic variation that affect disease and health (see Nature 412, 105; 2001). Microarray technology developed by Illumina of San Diego, California, will be used in the United States, Britain and Canada to produce about half of the HapMap data.

But Illumina faces a legal demand from biotechnology giant Applera, based in Norwalk, Connecticut, for $\$ 30$ million in damages - slightly more than Illumina's operating expenses for last year.

Applera's subsidiary company Applied Biosystems in Foster City, California, invested $\$ 10$ million in Illumina in 1999 as part of a plan to develop new genotyping technologies. Illumina says that Applera failed to fulfil its contractual obligations, such as providing reagents, and over the past year both firms have been developing their own technologies.

Last December, Applera sought to resolve the dispute through arbitration. Fearing that it could lose the rights to continue work on its core technology, Illumina filed a suit against
Applera alleging that the arbitration was intended to put it out of business. The arbitration was blocked by a state court in San Diego in February, but Applera has since filed a counter-suit. Illumina says that Applera is demanding \$30 million in return for work on the collaboration and its initial investment.

Illumina has informed its shareholders that the litigation could have an "adverse affect on its business, financial conditions and results of operations" if it is unable to defend itself successfully.

Timothy Kish, Illumina's vice-president and chief financial officer, told Nature that the legal action will not stop the company supplying its microarray technology to HapMap scientists. But lawyers for the company said the case could have a severe impact on the HapMap project.

Applera officials declined to be interviewed, but issued a statement saying that the firm's intention was to protect its investment, not to interfere with scientific research.

Researchers on HapMap projects in the United States and Britain say they are only vaguely aware of the litigation. "Potentially, we are concerned," says David Bentley, a geneticist at the Wellcome Trust Sanger Institute near Cambridge, UK, although he adds that he is confident that Illumina will be able to honour its agreements. group at the Harvard-Smithsonian Center for Astrophysics in Cambridge, Massachusetts, who has received one of the NASA grants. NASA, the US Department of Defense, student researchers and small companies have all flown tether experiments in space with limited success. A pair of US-Italian tethers that were unfurled from the space shuttle in 1992 and 1996 proved that tethers could produce current when dragged through the Earth's upper atmosphere, but hardware problems cut both experiments short.

A NASA-funded tether experiment, known as the Propulsive Small Expendable Deployer System or ProSEDS, was to have been launched this spring. The system would have been deployed from the spent stage of the Delta rocket that launched it. By interacting with the Earth's magnetic field, the tether would have dragged the rocket back and released it into the atmosphere, where it would have burned up.

The experiment was intended to show that tethers can be used to clear space junk without using rocket fuel. But after the accident involving the space shuttle Columbia, NASA rescheduled the launch for next February. The agency was worried that if something went wrong, the space station would have to use precious manoeuvring fuel to avoid a wayward tether.

Lorenzini and other researchers in the field see the mission as a key milestone in winning confidence that tethers are safe and practical. If the experiment is successful, they believe that other applications will follow. Pioneers in the field say that last week's grant also shows a new level of spaceagency support for more advanced tetherpropulsion ideas.

Robert Hoyt of Tethers Unlimited in Lynnwood, Washington, is another of the researchers who has been given a grant by NASA. "It's the first time what I would call real NASA money has been spent on the concept," he says. 